\title{
RATIONALE OF THE RULE THAT AN OBLIGEE'S PREMA- TURE PAYMENT DISCHARGES HIS SURETY
}

\section{H. W. Arant $\dagger$}

There is perhaps no more interesting bit of evolution of legali principle than that which has been taking place, since about I900, in the law of suretyship as to the effect which an obligee's premature payment to the principal debtor has upon his right against his surety.

Almost a hundred years ago, in Calvert v. The London Dock Company, ${ }^{1}$ the English Court of Chancery decided that such a payment totally discharged the surety on a contractor's bond. In that case, the principal had agreed to furnish the labor and materials for construction and repairs upon the defendant's property in consideration of the defendant's promise to pay $\mathfrak{f}_{52,000}$. The agreement provided that payment should be made every two months for three-fourths of the cost of the work certified by the architect to have been done, the remaining one-fourth to be paid upon the full completion of the contract. The plaintiff's testator and other sureties executed their bond to the defendant conditioned to be void if the principal performed his contract. Subsequently the principal became embarrassed financially and the obligee, for the purpose of enabling him to continue the work, made advances in excess of three-fourths of the cost of the work certified to have been done. Finally, however, the principal quit the job and subsequently was adjudged bankrupt. The surety filed a bill in equity praying that the defendant be perpetually enjoined from suing at law upon the bond on the ground that the obligee's premature payments had terminated the plaintiff's obligation arising from his execution of the bond. Holding that the defendant should be perpetually enjoined, the court said:

"The argument however, that the advances beyond the stipulations of the contract were calculated to be beneficial to the sureties, can be of no avail. . . . In almost every case where the surety has been released, either in consequence of time being given to the principal debtor, or of a compromise being made with him, it has been contended, that what was done was beneficial to the surety, - and the answer has always been, that the surety himself was the proper judge of thatand that no arrangement, different from that contained in his contract, is to be forced upon him; and bearing in mind that the surety, if he pays the debt, ought to have the benefit of all the securities possessed

$\dagger$ †. S., University of Alabama. IوIo; B. A., IgII: M. A., I9I2; LL. B., I915, Yale University; LL. D., University of Alabama, I930; Dean, Ohio State University Law School; author of CASES ON SURETYSHIP (I93I) ; SURETYSHIP (I93I) ; contributor of numerous articles to legal periodicals.

${ }^{1} 2$ Keen 638 (I838). 
by the creditor, the question always is, whether what has been done lessens that security." 2

Concerning the nature of the benefit resulting from the enforcement by the obligee of such a retention clause, the court said:

"In this case, the company were to pay for three-fourths of the work done every two months; the remaining one-fourth was to remain unpaid for till the whole was completed; and the effect of this stipulation was, at the same time, to urge Streather to perform the work. and to leave in the hands of the company a fund wherewith to complete the work if he did not; and thus it materially tended to protect the sureties.

"What the company did was perhaps calculated to make it easier for Streather to complete the work if he acted with prudence and good faith; but it also took away that particular sort of pressure which, by the contract, was intended to be applied to him. And the company, instead of keeping themselves in the situation of debtors, having in their hands one-fourth of the value of the work done, became creditors to a large amount, without any security; and under the circumstances, I think that their situation with respect to Streather was so far altered, that the sureties must be considered to be discharged from their suretyship." 3

Some twenty years later, in The General Steam-Navigation Company v. Rolt, ${ }^{4}$ the same type of situation was again before the English court and the same conclusion was reached. In the Court of Common Pleas, Chief Justice Cockburn emphasized the fact that the anticipatory payment to the principal causes loss to the surety of "the strong inducement which otherwise would have operated upon his mind to induce him to finish the work in due time." Crowder, J., observed that this must necessarily prejudice the surety. Wills, J., relying on Lord Eldon's statement in Samuel v. How$a r t h,{ }^{5}$ said "it is no answer to say that it is for the advantage of the surety, or that he has sustained no prejudice." On appeal to the Exchequer Chamber, Pollock, C. B., pointed out that, prima facie, the surrender of money which could have been retained as security for the principal's performance prejudiced the surety by depriving him of the benefit of the fund with which the obligee might in the first instance have indemnified himself, adding an expression of doubt as to whether it could have been proved that there was in fact no prejudice to the surety.

These decisions were very generally followed until about twenty-five years ago when the corporate, compensated surety began to appear as de-

"Ibid. at 644. The italics are the writer's.

${ }^{3}$ Ibid. The italics are the writer's.

46 C. B. N. S. 550 (1859).

${ }^{\circ} 3$ Mer. 272 (1817). 
fendant in such cases. ${ }^{6}$ Since that time, the decisions have not been unanimous. At first, the courts very generally followed the rule laid down in Calvert $v$. The London Dock Company ${ }^{7}$ and a few courts very recently have taken the same view, relying upon some one of the reasons urged in the decisions referred to above. ${ }^{8}$ A good many courts, however, refuse to

${ }^{6}$ Taylor v. Jeter, 23 Mo. 244 (1856) ; Bragg v. Shain, 49 Cal. I3I (1874) ; Lucas County v. Roberts, 49 Iowa 159 (I878); Ryan v. Norton, 65 Tex. 258 (I886): Simonson v. Thori, 36 Minn. 439, 31 N. W. 86r (1887) ; Fitzpatrick v. McAndrews, I2 Pa. C. C. 353 (1888); Kiessig v. Allspaugh, 9I Cal. 24I, 27 Pa.c. 255 (I89I) ; Evans v. Graden, I25 Mo. 72, 28 S. W. 439 (I894) ; Backus v. Archer, I09 Mich. 666, 67 N. W. 913 (1896) ; Bell v. Trimby, 38 S. W. I00 (Tenn. I896) ; City Council of Greenville v. Ormand, 5I S. C. I2I, 28 S. E. I47 (I897); Peters v. McKay, 20 Wash. I72, 54 Pac. II22 (I898); Cowdery v. Hahn, I05 Wis. 455, $8 \mathrm{I}$ N. W. 882 (I900); Wehrung et al. v. Denham, 42 Or. 386, 7I Pac. I33 (I903); Glenn County v. Jones, I46 Cal. 518, 80 Pac. 695 (I905) : Kunz v. Boll, I40 Wis. 69, I2I N. W. 60I (I909); Lyons v. Kitchell, I8 N. M. 82, I34 Pac. 213 (Igr3); McKnight v. Lange Mfg. Co., I55 S. W. 977 (Tex. Civ. App. I913); Williams v. Baldwin, 228 S. W. 554 (Tex. Civ. App. I92I).

In the following cases the acconmodation surety was discharged only to the extent of the amount prematurely paid. Weik v. Pugh, 92 Ind. 382 (I883) ; Pickard v. Shantz, 70 Miss. 38I, I2 So. 544 (I89.3) ; Gray v. School Dist. of Norfolk, 35 N Neb. 438, 53 N. W. 377 (1892); Maree v. Ingle, 69 Ark. I26, 6I S. W. 369 (Igor) ; Cochran v. Baker, 34 Ore. 55.5. 56 Pac. 64I (I899) ; Burr v. Gardelia, 53 Cal. A pp. 377, 238 Pac. Ior (I92I) (under a statute providing that a surety is exonerated "to the extent to which he is prejudiced by any act of the creditor which would naturally prove injurious, etc.")

In the following cases the premature payment was no discharge to an accommodation surety. Haine v. Dambach, 4 Pa. C. C. 633 (I885); Presbyterian Church v. Conlin, II Pa. Super. 4I3 (i899); Myers v. Wood, 26 Tex. Civ. App. 59I, 65 S. W. 671 (Ig0I) ; First Presbyterian Church v. Housel, II5 Ill. ADD. 230 (I904): Myers v. Lane, II6 Ky. 566,76 S. W. 399 (Ig03). See Northern Light Lodge v. Kennedy, 7 N. D. 146, 73 N. W. 524 (I897) ; Mazzera v. Ramsey, 72 Cal. App. 601, 238 Pac. Ior (I925).

A premature payment has been held not to discharge an accommodation surety if the amount paid is subsequently deducted from payments to which the principal is entitled. Hand Mffg. Co. v. Marks, 36 Ore. 523, 59 Pac. 549 (1900); Mazzera v. Ramsey, supra.

Sometimes the surety is not discharged because the deviation in payment is authorized by the contract. Moore v. Fountain, 8 So. 509 (Miss. I89I) ; Enterprise Hotel Co. v. Book, 48 Ore. 58,85 Pac. 333 (I906).

In Tarkington Prairie Lodge, etc., v. George W. Smyth Lumber Co., 214 S. W. 588 (Tex. Civ. App. I9I9), a premature paynent was held not to discharge an accommodation surety because of a statutory provision that "No change or alteration in the plans, building, construction, or method of payment shall in any way avoid or affect the liability on said bond, and the sureties on said bond shall be limited to such defenses only as the principal on said bond could make." But in Williams v. Baldwin, 228 S. W. 554 (Tex. Com. App. Ig2I), it was said that this statute was held unconstitutional in Hess. v. Denman Lumber Co., 2I8 S. W. I62 (Tex. Civ. App. I920), as an unwarranted interference with the freedom of contract.

${ }^{7}$ St. Mary's College v. Meagher, in S. W. 60 S (Ky. I889) ; Jersey City Water Supply Co. v. Metropolitan Const. Co., 76 N. T. L. 419, 69 At1. I088 (I908) ; Kelsay Lumber Co. v. Rotsky, I78 S. W. 837 (Tex. Civ. App. 1915); First Nat. Bank v. Fidelity \& Deposit Co., I45 Ala. 335, 40 So. 4I5 (I906) (expressly overruling Fidelity \& Deposit Co. of Md. v. Robertson, I36 Ala. 379, 34 So. 933 (1903)) ; Fidelity \& Deposit Co. v. Agnew, I52 Fed. 955 (C. C. A. 3d, 1907); Wells v. National Surety Co., 222 Fed. 8 (C. C. A. 3d, 1915); Fels \& Co. v. Massachusetts Bonding \& Ins. Co., 48 Pa. Super. 27 (IgII); Neilson v. Title Guaranty \& Surety Co., 81 Ore. 422 , 159 Pac. II5I (1916). In City of Everett v. Snyder, I03 Wash. 445, I74 Pac. 643 (I918), the surety was totally discharged where the obligee paid the balance of the contract price before completion and while construction was suspended at its order.

In First Nat. Bank v. Fidelity \& Deposit Co., supra, the court said: "The cases referred to by appellant's counsel, which hold that, where a collateral security has been released, or lost, without the consent or fault of the surety, said surety is released only pro tanto, do not apply to a case like this, even as to the Io per cent. reserve. Said provision in this case is one of the conditions of the contract, and it cannot be said that it is a mere security for the payment of such money; but is is reserved as much as a stimulus to insure the completion of the work by the contractor, as for a mere security of the amount of money." At 347, 40 So. at 4I8.

${ }^{8}$ Commercial Casualty Co. v. Durham County, I90 N. C. 58 , 128 S. E. 469 (1925); Fidelity \& Deposit Co. of Md. v. Kelsay Lumber Co., 33 S. W. (2d) 73 I (Tex. Com. App. 
accept this argument when offered in behalf of a corporate compensated surety. ${ }^{9}$ Their reasoning usually begins with a statement that a compensated surety is an insurer and, having thus tagged the defendant, the case is regarded as withdrawn from the category of suretyship. It is then concluded that such a surety is not discharged unless the premature payment causes it injury. Some courts go so far as to hold that the burden of proving the existence and extent of such injury is upon the surety, ${ }^{10}$ but their language often suggests that, if any injury is shown, even such a surety's discharge is total. ${ }^{11}$ Nevertheless, actual decisions are making it increasingly

1930). In Park Presbyterian Church of Italy v. Wm. Cameron \& Co. Inc., $38 \mathrm{~S}$. W. (2d) gor (Tex. Civ. App. 193I), after stating that it was bound by the preceding and earlier decisions, the court said: "If it were a question of first impression, we think the correct and much more equitable rule would be that the surety should only be released from the bond to the extent that funds had been paid by the owner to the contractor not authorized by the contract, unless the surety established the fact that it had been otherwise injured. . . . It appears to be almost a travesty on justice to say that, because the church paid the contractor $\$ 8.50$, which it should not have paid under the strict terms of the contract, it thereby released the surety company from paying the additional $\$ 3,000$ required to complete the building and release the liens fixed thereon." At 903.

Sometimes the surety's discharge is based on express provisions in his agreement. Justice v. Empire State Surety Co., 209 Fed. I05 (E. D. Pa. I913); O'Neil v. Title Guaranty \& Trust Co., IgI Fed. 570 (C. C. A. 6th, IgIX); Long v. American Surety Co. of N. Y., 23 N. D. 492, I37 N. W. 4I (I912); Inland Navigation Co. v. American Surety Co., I90 Ky. 504, 227 S. W. 809 (Ig2I) : Detroit Fidelity \& Surety Co. v. Bushong, 175 N. E. 68.3 (Ind. I93I).

${ }^{\circ}$ In the following cases the surety was discharged to the extent of the premature payment. St. John's College v. Aetna Indemnity Co., 20r N. Y. 335, 94 N. E. 994 (IgrI) ; Grant v. Alfalfa Lumber Co., I77 S. W. 837 (Tex. Civ. App. I9I5); Maine Cent. R. R. v. National Surety Co.. II3 Me. 465, 94 Atl. 929. L. R. A. I9I6A 88I (I9I5); Southern Real Estate \& Financial Co. v. Bankers' Surety Co., I84 S. W. I030 (Mo. 19I6); Village of Canton v. Globe Indemnity Co., 201 App. Div. 820, I95 N. Y. Supp 445 (I922); Paxton v. Spencer, 7I Utah 3I3. 265 Pac. 75I (1928) (express condition in bond) : Globe Indemnity Co. v. Southern Pac. Co., 30 F. (2d) 580 (C. C. A. 2d, r929) (former appeal, 22 F. (2d) 288 (C. C. A. $2 \mathrm{~d} 1927$ )); Crouse v. Stanley, 100 N. C. I86, I54 S. E. 40 (1930); Fort Worth Independent School Dist. v. Aetna Casualty \& Surety Co., 48 F. (2d) I (C. C. A. 5th, I93I). See Aetna Casualty \& Surety Co. v. Robertson Lumber Co., 3 S. W. (2d) 89.5 (Tex. Civ. App. I928) ; McNally v. Mercantile Trust Co., 204 Pa. 133, 54 Atl. 360 (1903).

In the following cases the premature payments resuited in no discharge whatever. Stevens v. Elwer, Ior Wis. 392, 77 N. W. 737 ( I898); Central Lumber Co. v. Kelter, 201 I11. 503, 66 N. E. 543 (1903); Leghorn v. Nydell, 39 Wash. 17, 80 Pac. 833 (Ig05); American Surety Co. of N. Y. v. Scott \& Co., I8 Okla. 264, 90 Pac. 7 (Ig07); Monro v. National Surety Co., 47 Wash. 488,92 Pac. 280 (I907); Allen v. Everoth, II8 Minn. 476, I.37 N. W. I6 (I9I2): Lackland v. Renshaw, 256 Mo. 133, I65 S. W. 3I4 (I9I4) : Manhattan Co. v. United States Fidelity \& Guaranty Co., 77 Wash. 405, I37 Pac. I003 (10I4) ; Dunne Investment Co. v. Empire State Surety Co., 27 Cal. App. 208, 150 Pac. 405 (I9I5) : School District v. United States Fidelity \& Guaranty Co., 96 Kan. 499, I52 Pac. 668 (I915): Fort Dodge, D. M. \& S. R. Co. v. Burns, I77 Iowa 51 , I 58 N. W. 582 (I916) ; Trustees of M. E. Church, etc. v. Equitable Surety Co., 269 Pa. 4 II, 112 At1. 55 I (I92I) ; Maryland Casualty Co. v. Eagle River Union Free High School Dist., I8s Wis. 520,205 N. W. 926 (1925).

${ }^{10}$ National Surety Co. v. Haley, 58 Okla. 263, 159 Pac. 292 (1916); Maryland Casualty Co. v. Eagle River Union Free High School Dist.; Lackland v. Renshaw; Dunne Investment Co. v. Empire State Surety Co.: Trustees of M. E. Church, etc. v. Equitable Surety Co., all sipra note 9 .

1 For example, in Lackland v. Renshaw, supra note 9, the court said: "When installments under a contract secured by an accommodation surety are paid before they are due, and without the surety's consent. the rule is well established that the surety is thereby released. In such case the injury to the surety is presumed. This is a result of the doctrine that the surety is a favorite of the law. The retention of installments by the obligee until the work reaches the prescribed stage is said to furnish an incentive to the contractor to complete the work within the prescribed time. Ought a presumption of injury, or that the surety's risk was increased, be indulged in this case? The referee finds expressly that all these sums went to pay for labor and materials actually employed in the construction of the building. This 
clear that this implication is not intended and that the extent of the injury proved measures the compensated surety's discharge. ${ }^{12}$

The frequency with which this problem continues to be presented to the courts, the conflict of decision, the variety and haziness of the reasoning adduced in its support, as well as its intrinsic interest from the point of view of evolution of legal principle, must be the justification for a reexamination of this matter.

One of the reasons occasionally given for. discharging the surety under such circumstances, doubtless suggested by the concluding sentence of the quotation above from Calvert $v$. The London Dock Company, is that the obligee's premature payment to the principal is an alteration of the surety's contract. ${ }^{13}$ But it seems clear that there is no "alteration" of the "contract" in any ordinary sense. The term "contract" is frequently used to denote: "( I) the operative acts of the contracting parties, such as promises, other expressions of assent, performances constituting the consideration for a promise, the sealing and delivery of a document; $(2)$ the physical document in writing, containing the terms of the agreement; (3) the jural relations of the two parties created by their operative acts and by the document (if any)." 1-t In the type of case here discussed, it is clear that there can be no alteration of the "contract" in the first sense and no case has been observed where the surety's discharge was due to payments made pursuant to alterations of the "contract" in the second sense. That the premature payment causes some change in the totality of jural relations between the parties cannot be denied and there is a seeming alteration of the "contract" in the third sense. Such a payment, like a payment which is made when due, is a part performance by the obligee which causes a quantitative diminution of the principal's right to payment upon completion. But the surety's tmdertaking was to secure the principal's performance of his duty and the payment does not affect the principal's duty either quantitatively or qualitatively; full performance on his part requires the same action as would have been required had there been no excess payment; he merely receives a part of his compensation sooner than he has a right to receive it. ${ }^{15}$. The

finding conclusively disproves iniury as a fact. That being true, and the presumption of injury under like circumstances, in favor of an accommodation surety being indulged because of the rule that such surety is a favorite of the law and that rule being applicable to a surety whose engagement is undertaken for compensation, no presumption of injury found as a fact not to have occurred ought to be indulged to release such a surety." At I45, 165 S. W. at 3I7.

${ }_{12}$ Allen v. Everoth: Dunne Investment Co. v. Empire State Surety Co.: American Surety Co. of N. Y. v. Scott \& Co.: Manhattan Co. v. United States Fidelity \& Guaranty Co.: Monro v. National Surety Co.: Fort Dodge, D. M. \& S. R. Co. v. Burns; Crouse v. Stanley, all supra note 9 .

${ }^{13}$ Simonson et al. v. Thori; City Cauncil of Greenville v. Ormand; McKnight v. Lange uIfg. Co., all supra note 6 ; City of Everett v. Snyder, supra note 7 . See also Globe Indemnity Co. v. Unity Rys., 272 Fed. 607 (C. C. A.3d, I92I).

${ }^{14}$ ANson, Contracts (Corbin's ed., I924) \$ 9, n. 2.

${ }^{25}$ The same kind of alteration of the jural relations created by the agreement would occur if the principal paid part of a debt which had been guaranteed before maturity. The payment would decrease both the obligee's right and the principal's duty but such an alteration should 
obligee's failure to exercise his privilege not to pay until completion can hardly be considered even a breach of the contract inasmuch as he has made no promise to retain the stipulated percentages either to the principal or to the surety. Furthermore, since the obligee can refuse to make further advance payments, the relations of the parties resulting from the original agreement are not altered as to the future by a premature payment.

But, in order to discharge the surety, the "alteration" should be an alteration of his contract. The substance of his contract is that the principal will perform in accordance with his promise. The cases which totally discharge the accommodation surety actually, though not professedly, make retention of percentages in accordance with the obligee's privilege a condition precedent to the surety's duty. But, if a provision requiring such a consequence were expressly inserted in the surety's agreement, the payment would operate as a condition subsequent and would not be an alteration of the "contract" in any ordinary sense. ${ }^{10}$

The argument quoted above that the obligee's premature payment operates as a surrender of security, which must discharge the surety, cannot be so shortly dismissed. Nothing was better settled in the law of suretyship, when Calvert v. The London Dock Company was decided, than that an obligee's surrender of security discharges the surety to the extent of the value of the security released, inasmuch as the surety is thereby, and to that extent, deprived of the means of collecting what may become due him from the principal debtor. ${ }^{1 \tau}$ But there is difficulty in applying this rule to the type of case here being considered, because of the difficulty in determining the security-value of a retained percentage. This difficulty will next be considered and then the question raised as to the soundness of the basic rule

not discharge the surety. None of the parties contemplated, when the contract was made, that the principal would wish or be able so to pay, but, if his ability and desire so to pay had been considered, the surety undoubtedly would have agreed that the obligee's receipt of such a payment would have no effect upon his obligation. This could not be said of the resulting situation in City of Everett v. Snyder, supra note 7, where the principal contracted to construct sidewalks and pavements which were to be completed within sixty days. The obligee ordered work suspended in order to allow certain fills to settle and paid the entire contract price, the agreement with the principal providing for retention of 30 per cent. of the price agreed until completion. Holding the surety not liable when the principal refused to resume work a year later, the court said the surety was prejudiced because, first, "the life of the contract was extended about a year" and, second, because the full payment left the principal without incentive to finish and because the 30 per cent. to be retained "was a fund which the surety had a right to rely upon to pay whatever claims might be filed against the bond".The act of the city "made a very different contract from the one which the surety company undertook to guarantee." This decision might easily be justified on the ground that the obligee prevented the performance guaranteed.

${ }^{10}$ Haine v. Dambach: Fitzpatrick v. McAndrews; Myers v. Wood, all supra note 6; Manhattan Co. v. United States Fidelity \& Guaranty Co., supra note 9: Smith v. Malleson, I48 N. Y. 24I, 42 N. E. 669 (1896).

In Maine Cent. R. R. v. National Surety Co., supra note 9 , the court said: "An advance of money by an owner to his contractor before a payment becomes due under the building contract does not necessarily operate as an alteration of the contract itself. Whether it has that effect depends, we think, upon the amount of the payment and the conditions and circumstances under which it was made, considered in connection with the rights and obligations of the surety under his contract of suretyship." At 473, 94 Atl. at 932.

${ }^{17}$ See cases cited supra note $4 ; 2$ WILLISTON, Contracts (Ist ed. I920) § I232. 
that an obligee's release of security automatically discharges the surety pro tanto.

That security of the obligee is the purpose of a retention clause such as is here being considered is undeniable. Nor would it be questioned that, under ordinary circumstances, retention of the stipulated percentage produces an incentive to complete performance which grows as performance progresses; the nearer the principal approaches the end of his job, the larger the amount of money already expended which he can get from the obligee only by completion. ${ }^{18} \mathrm{But}$, the effectiveness as security of such a growing incentive necessarily assumes the principal's power to complete performance. When the contract is entered into, his capacity then to perform, as well as its continuance, is doubtless assumed by all parties concerned. On this assumption the enforcement of a retention clause would then appear to be wise and beneficial to the obligee-and incidentally to the surety-because it then appears that its enforcement will enhance the probability of the principal's performance. When, however, unexpected difficulties have deprived the contractor of the ability to finish, his incentive or desire to perform cannot assert itself as contemplated and it ceases to have any value as security either to the obligee or to the surety. ${ }^{19}$ Additional operating capital is now necessary if whatever desire the principal has to perform is to have a chance to assert itself. It cannot be assumed that the contractor will have no incentive to finish or that he will abandon the contract merely because further performance is unnecessary to obtain payment of a percentage of the cost of production already expended. ${ }^{20}$ The release of percentages already earned can have no practical effect upon the security-value of the principal's incentive to perform, since the ordinary compulsions to perform remain and the special incentive created by retention of percentages was rendered impotent by the circumstances which produced the contractor's disability to proceed. But, as long as the principal can continue performance without the premature payment, such special incentive obviously has a real value as security, but it is also obvious that its value is not capable of measurement. This is the strongest justification that can be given

${ }^{18}$ In Kunz v. Boll, supra note 6, the court said: "The efficacy of substantial advance payments upon contracts to discharge sureties is too well settled by the authorities in this state to warrant discussion. The prejudicial effect thereof to the surety has been found both in the removal of the incentive to the contractor to diligently press his work and from the diminution of the fund which the contract contemplates to remain in the owner's hands and which may serve as a means of protecting the sureties from liabiltiy." At 71, r21 N. W. at 602.

${ }^{19}$ See First Presbyterian Church v. Housel, supra note 6 ; St. John's College v. Aetna Indemnity Co.: Fort Dodge, D. M. \& S. R. Co. v. Burns; Trustees of M. E. Church v. Equitable Surety Co., all sipra note 9.

${ }^{20}$ British-American Tobacco Co. v. United States Fidelity \& Guaranty Co., I77 App. Div. 582, 164 N. Y. Supp. 406 (I917); Village of Canton v. Globe Indemnity Co.; Maryland Casualty Co. v. Eagle River Union Free High School Dist., both supra note 9.

In Globe Indemnity Co. v. Southern Pac. Co., supra note 9, the court said: "No case is cited holding that the surety is completely released by an advance payment without the consent of the surety, where it appears, as here, that the payment was made on the eve of abandonment of the contract and appointment of receivers of the principal, so that the contractor's incentive to prosecute the work cannot have been affected." At 58I. 
for the rule so well settled in the accommodation surety cases that any premature payment totally discharges the surety. As there applied, however, it is assumed that there can be no circumstances under which the obligee may waive the retention clause without the surety's approval ${ }^{21}$ and that such a payment always results in the loss of security which has value. But, if it be conceded that incentive to complete, under ordinary circumstances, has a real but necessarily indeterminate value as security, it is obvious, as pointed out above, that its security-value disappears when the contractor becomes unable to proceed.

In Calvert v. The London Dock Company, it was pointed out that the retained percentage operates as security in another manner; if the principal defaults, it can be used by the obligee to indemnify himself against the resulting loss. In this respect also, enforcement of the retention clause produces a security which becomes more adequate as performance actually progresses. But payment of an accumulated percentage, as a practical matter, deprives the surety of a source of indemnity only on the assumption that it results in no advancement of performance which would not have taken place without it. At any time after performance has begun, the obligee is manifestly worse off, from a security point of view, if he does not have a retained percentage for use as a means of completion. But, if a percentage which might have been retained is so used that it proportionately advances performance, after the contractor has become unable to proceed, it is clear that the principal's subsequent default leaves the obligee no worse off from a security point of view. Of course, he has not the money in his hands which he might have had with which to indemnify himself, but, under the circumstances supposed, it will have been wrought into performance which otherwise could not have occurred and the damage against which he needs indemnity is decreased to the extent of the advance. Hence, it is obvious that a percentage which might be retained may be made available to the contractor as operating capital without any damage either to the obligee or to his surety. This result, however, assumes that the payment is made to enable an embarrassed principal to continue performance, and that it has that consequence.

If a provision for the retention of percentages is security, whatever the conception as to how or why it secures performance, it would be unanimously conceded that the surety's so-called "right" of subrogation attaches to it and, in practice, enforcement of the provision is a condition precedent to the obligee's right against an accommodation surety. The consequence of this rule is to deprive the obligee of the power to make a subsequent judg-

II First Nat. Bank v. Fidelity \& Deposit Co., supra note 7 , the court said: "While, as between the original parties to the contract, either party may waive any of its provisions, yet when a third party becomes interested in the contract by binding himself to its faithful execution, the contract becomes a part of his obligation, and its provisions cannot be waived so as to affect his interest without his consent. . . Said provision in this case is one of the conditions of the contract,..." At 346,40 So. at 4 I 8 . 
ment, without prejudice to his right against the surety, as to what it is best to do when the principal's contemplated ability to perform without the aid of the retained percentages no longer exists. Moreover, this rule appears to be at variance with recognized principles applicable in analogous suretyship situations. The sole object of the contract, secured by the surety's promise, is receipt by the obligee of the promised performance from the principal. The retention clause is security which the principal himself gives; the surety's undertaking supplements it. Each, however, is security to the same end. The stipulated percentage, as a means of indemnity to the obligee, is not essentially unlike pledged or mortgaged property, and its use, as above supposed, is analogous to the creditor's sale of pledged or mortgaged property and the application of its proceeds to the payment of his debt, with the unimportant difference that such sale and application usually takes place after maturity of the principal's obligation. But if, by agreement with the principal, such pledged or mortgaged property should be fairly sold before maturity and its proceeds applied to indebtedness upon which the principal's default appeared certain, it is hardly conceivable that such a handling of the security would discharge the surety to any greater extent than it discharges this principal. The security would have been used to its full capacity for the purpose for which it was intended. This appears to be the substance of what happens when the obligee makes a premature payment to an embarrassed principal which is actually utilized to promote performance. The percentage, in one of its security aspects, is fully utilized as a means of completing the unfinished work of the principal, and in this regard it is doubtless used as the parties would have contemplated had they anticipated the circumstances which have occurred. The other element of the security, which consists of the principal's incentive to complete, has become worthless because of his inability to proceed and it is well settled that the creditor's release of worthless security has no effect upon the surety's obligation. $^{22}$

If the obligee obtains the surety's consent to the advance, his right against the surety is unquestionable, but if the surety should object, though there is little or no authority on the precise point, it is safe to say that the creditor's payment would be held totally to discharge an accommodation surety, irrespective of the prudence or harmlessness of the payment. ${ }^{23}$ If this is so, the surety has the power to veto the waiver of a clause which, it appears reasonable to assume, was put into the contract primarily for the security of the obligee and which it was assumed would operate upon a principal able to perform. Such a consequence is seldom required by express

$\cong$ Hardwick v. Wright, 35 Reav. I33 (Eng. I865); Rainbow v. Juggins, L. R. 5 Q. B. D. 422 (I880); Blydenburgh v. Bingham, $38 \mathrm{~N}$. Y. $37 \mathrm{I}$ (I868); Lilly v. Roberts, $58 \mathrm{Ga} .363$ (I877) ; Green v. Blunt, 59 Iowa 79, I2 N. W. 762 (r882) ; First National Bank v. Parsons,

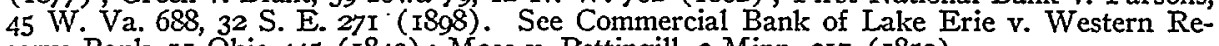
serve Bank, II Ohio 445 (1842); Moss v. Pettingill, 3 Minn. 2I7 (I859).

${ }^{3}$ See First Nat. Bank v. Fidelity \& Deposit Co., supra note 7 . 
contract provision and can be justified only by some equitable consideration. When there is reasonable ground to believe that the advancement is necessary to enable the principal to avoid default and it is so made as to result in a proportionate promotion of performance, the basis of the countervailing equity which produces the surety's discharge is not apparent. Judged by the intent ordinarily expressed in the instrument in which such a retention clause appears, the obligee is the sole owner of the resulting security ; ${ }^{24}$ yet, the courts have given the accommodation surety absolute control of it. Thus to magnify the accommodation surety's so-called "right" of subrogation and deny the creditor the freedom to make a prudent attempt to obtain from the principal what he promised him appears to reverse the positions of that which was contemplated as primary and that which should be regarded as accessory or supplemental. The function of the surety is to secure the creditor in the enjoyment of the performance promised by the principal. It seems reasonable to assume that his undertaking is intended to operate as a security so long as the creditor acts with good faith and reasonable prudence. Advancing percentages which might be retained, under some circumstances, is consistent with both. The language quoted from the English cases suggests that the surety not only expects, when he contracts, that the retention clause will be literally enforced but that he has such ground for expecting this as exists either when the obligee promises not to pay prematurely or when his own promise is expressly conditioned upon the obligee's retention of the stipulated percentages. ${ }^{25}$ That there is a difference between the obligee's promising not to pay and his reservation of a privilege not to pay is obvious. A promise not to pay which would tie the obligee's hands could be of no benefit either to him or to the principal in advancing the objective of the contract. ${ }^{20}$ Only the surety could possibly be interested in such a provision and, as has been shown, circumstances often arise which would make its enforcement of no value to him. But the provisions in such a contract must be assumed to have been inserted primarily for the benefit of the obligee. The fact that they appear in the form of a reservation rather than in the form of a promise justifies the view that the clause creates an option in the obligee. To hold that the surety must be consulted is to hold, substantially, that the option belongs to him.

Where the surety is compensated, as has been stated, courts now generally reach a conclusion at variance with that arrived at in Calvert $v$. The London Dock Company. ${ }^{2 \pi}$ In the beginning, as was natural, the courts

2s Haine v. Dambach; First Presbyterian Church v. Housel; Northern Light Lodge, etc. v. Kennedy, all supra note 6; Central Lumber Co. v. Kelter; School District v. United States Fidelity \& Guaranty Co., both supra note 9; Harlan Fuel Co. v. Wiggington, 203 Ky. 546, 262 S. W. 957 (1924).

$\approx$ See Paxton v. Spencer, supra note 9.

${ }^{\infty}$ See Central Lumber Co. v. Kelter, sitpra note 9.

${ }^{27}$ See cases cited supra note 9 . 
were troubled by the implications of the term "surety". ${ }^{28}$ The existence of the general rule that the obligee's premature payment totally discharged the surety could not be denied. How could refusal to apply so well-recognized a principle to such sureties be justified? This doubtless appeared to present a real difficulty if a proper respect was to be shown to the doctrine of stare decisis. To some courts there seemed to be no effective way to surmount it except to deny that such a defendant was a surety at all. For example, in a recent $W$ isconsin case, the court said:

"It is thoroughly established by the decisions of this court that contracts of this kind, entered into for a consideration by surety companies engaged in such business, are in effect contracts of insurance, and the contracts are not to be construed according to the rules of law applicable to the ordinary accommodation surety." 29

Having determined that the contract under consideration is a contract of insurance rather than a contract of suretyship, the inapplicability of the rule that a premature payment to the principal totally discharges his surety was considered to have been conclusively demonstrated. But even so apparently complete an escape from suretyship concepts did not leave the courts entirely free to choose conclusions. The total discharge, so long accorded the accommodation surety, was repelled by the insurance label which also effectively forestalled those who might charge either that a surety had been denied its rights without justification or that a proper respect had not been shown for stare decisis. But, from the first, one reason given for holding that a retention clause operated as security was that the retained percentage might serve as a source of indemnity to the obligee if the principal defaulted, and the soundness of this reason seemed beyond question. Moreover, the value as security in this respect of a retained percentage was so definite that, on the surface at least, the conclusion appeared inescapable that one whose right of subrogation extended to this security was injured to the extent of the amount prematurely paid. There may have been reluctance to discharge, even to the extent of the percentage prematurely paid, one whose claim to the law's favoritism had been flatly denied, but it is easy to under-

$\approx$ See cases cited supra note 7.

@ Maryland Casualty Co. v. Eagle River Union Free High School Dist., supra note 9.

"While such corporations may call themselves 'surety companies', their business is in all essential particulars that of insurers. . . . The surety in this case is in no position to complain that the tenderness courts see fit to show the accommodation surety, always an object of the greatest solicitude, is not shown to it. Its situation is entirely different. It is to be dealt with in the light of its real relation to the contract an insurer of its performance. Lackland v. Renshaw, supra note 9, at $140,146,165 \mathrm{~S}$. W. at $315,317$.

In Trustees of M. E. Church, etc. v. Equitable Surety Co., supra note 9, the court said : "True, this bond contains the provision that it 'shall be construed strictly as one of suretyship only'; but in this commonwealth, as part of its declared public policy, bonds of the character of that here sued upon, which are given for a consideration, are to be so construed as to protect the obligee, and the language above quoted does not prevent our treating it as a 'suretyship' for profit, in accordance with the fact,. . . At 4I5, II2 Atl. at 552. (I9I6).

See also Barton v. Title Guaranty \& Surety Co., 192 Mo. App. 56r, I83 S. W. 694 
stand how the courts could have regarded it as practically impossible to escape discharging the compensated surety to this extent. The surety's right of subrogation had so long been said to entitle him to enjoy in specie his creditor's security that, when Calvert v. The London Dock Company was decided, a discharge to the extent of the amount prematurely paid would have seemed inevitable, even if the security-value of the incentive to complete resulting from the retention of percentages had never been recognized. Hence, a limitation of the discharge to the amount prematurely paid doubtless appeared to be the utmost limit justifiable by a court which had any respect for stare decisis and whose ability to avoid the total discharge depended upon calling the defendant an insurer. To refuse any discharge whatever would be to deny either that the compensated surety has the right of subrogation or to deny that impairment of that right as to security results in a pro tanto discharge. To deny the former was impossible because the compensated surety had been called an insurer and it was well settled that insurers had the right of subrogation. To deny the latter would have annihilated the fundamental basis of most of the law which specially appertains to sureties, and was unthinkable, if desirable.

Nevertheless, the soundness of such decisions appears questionable because they appear to give no weight to the circumstances under which the payment was made. They overlook the fact that the percentage which might have been retained and used as a means of indemnity may have been utilized by being wrought into performance which otherwise would not have taken place. If the percentage paid had been retained and used to continue performance through another from the point where the principal would have been forced to quit without it, it would not be seriously contended that the surety would be discharged. It should make no difference that the obligee, by means of the fund, obtains with less difficulty the same amount of performance through the principal. ${ }^{30}$ The fact that the principal's incentive to complete, in order to obtain payment of the retained percentage, has been rendered valueless as security by his inability to proceed is never considered. Because this latter element of the contemplated security has become worthless, its surrender often quite properly appears to have no weight but one reads the cases with a feeling that failure even to mention it indicates that the courts no longer recognize it as an element of security in compensated surety cases. This is notably true in some of the more recent cases where the compensated surety is denied any release whatever if the advances actually go into the job. ${ }^{31}$ In cases where this view is expressed, there is nothing to indicate that it is limited to cases where the payments

${ }^{30}$ See Fort Dodge, D. M. \& S. R. Co. v. Burns; Trustees of M. E. Church, etc. v. Equitable Surety Co., both supra note 9.

${ }^{31}$ Maryland Casualty Co. v. Eagle River Union Free High School Dist., supra note 9. See also Lackland v. Renshaw; School District v. United States Fidelity \& Guaranty Co., both supra note 9 . 
are made to relieve the contractor's embarrassment. Unless a payment is made for this purpose, it does not result in a measure of performance which would not otherwise have taken place, and, the contractor still being able to perform, the necessity of performing to obtain payment of the percentages still has a real, if indefinite, security-value. Moreover, by premature payment under such circumstances the obligee departs from the contemplated course of action where there is no intervention of unforeseen circumstances which makes his departure prudent, and refusal to discharge the surety to some extent seems impossible to justify.

The language used in the compensated surety cases generally indicates that the premature payment is regarded as a breach of duty to the surety. When thus regarded, the conclusion that it should bear the burden of proving the extent of the injury which measures its discharge accords with the general notion that he who complains of another's breach of duty must prove the extent of the resulting damage.

The creditor's failure to recover, however, may result either from his failure to perform an implied condition precedent or from his breach of an implied promise to the surety. ${ }^{32}$ Implication of condition and implication of promise alike are devices for the rationalization of desired results ${ }^{33}$ and the conditions and promises implied in suretyship cases are no exceptions. In nearly all the cases in which an accommodation surety was involved, the courts said that he had the right to be subrogated to all the obligee's security, and discharged him because the obligee's premature payment impaired it. Violation of this right by the obligee operated as a condition subsequent to the surety's duty to him. But this right was not derived from the contract; courts of equity created it because it was believed that one who gratuitously assumed the hazardous obligation of suretyship should have all the advantages which his obligee might have enjoyed. ${ }^{34}$ Sym-

${ }^{32}$ The condition or duty was almost invariably implied in character in the accommodation and early compensated surety decisions. It is not uncommon now, however, for the compensated surety to insert in its bond some provision indicating that it is to be liable only in the event that the obligee enforces the retention clause. Fuqua v. Tulsa Masonic Building Ass'n, r29 Okla. 106, 263 Pac. 660 (1928); Detroit Fidelity \& Surety Co. v. Bushong, supra note 8; Paxton v. Spencer, supra note 9. See School District v. United States Fidelity \& Guaranty Co.; American Surety Co. of N. Y. v. Scott \& Co., both supra note 9. Cf. Lena Lumber Co. v. Brickhouse, I73 Ark. 348, 292 S. W. ro07 (I927). In Trustees of M. E. Church, etc. v. Equitable Surety Co., supra note 9, the bond provided that "it shall be construed strictly as one of suretyship only", but the premature payment resulted in no discharge to the surety.

${ }_{33}$ "You always can imply a condition in a contract. But why do you imply it? It is because of some belief as to the practice of the community or of a class, or because of some opinion as to policy, or, in short, because of some attitude of yours upon a matter not capable of exact quantitative measurement, and therefore not capable of founding exact logical conclusions." Holmes, The Path of the Lare (I897) Io Harv. L. REv. $46 \mathrm{r}$, at 466.

"Considerations partly of justice and partly of presumable intention are to tell us whether this or that promise shall be placed in one class or in another." Cardozo, J., in Jacob \& Youngs v. Kent, 230 N. Y. 239 at 242 , I29 N. E. 889 at 890 (I92I), discussing the distinction between dependent and independent promises.

3t "The rule here is undoubted, and it is one founded on the plainest principles of natural reason and justice, that the surety paying off a debt shall stand in the place of the creditor, and have all the rights which he has, for the purpose of obtaining his reimbursement. It 
pathy for the surety having caused the creation of this right, it was unthinkable that its impairment would not be made to operate to his advantage. The law, however, long before the decision in Calvert v. The London Dock Company, was well settled that the obligee's release of such security as mortgages, pledges, liens, etc., discharged the surety only to the extent of the value of the security released. Discharge to any greater extent would have been difficult to justify logically, since the right to the creditor's security was created to provide a fund from which the surety could obtain reimbursement. $^{35}$ But, so much of the obligee's security as consisted of the incentive to complete, produced by enforcement of the retention clause, was obviously not susceptible of definite evaluation as a means of obtaining reimbursement. Unless its release discharged the surety totally, there would be a practical denial that the surety's right of subrogation included all the obligee's security. Such a denial, because of sympathy for the surety and the volume of judicial assertion to the contrary, was unthinkable. Thus did the courts appear to be driven to a conclusion in favor of the surety by the logical implications of the existence of a "right" which they implied in the beginning for the purpose of seeming to be so driven. The accommodation surety had a "right" that the obligee retain his security for him and it was doubtless the courts' sympathy for him that made the obligee's violation of it appear so serious that it was given the cast of a condition subsequent, whether the surety was injured or not, and irrespective of the circumstances under which the obligee acted. Not so, however, with the compensated surety, though the logic which seemed to compel the accommodation surety's total discharge seems equally compelling when the compensated surety's conceded "right" of subrogation ${ }^{36}$ is impaired, and it has been noted that this was the conclusion in some of the early compensated surety cases. ${ }^{37}$ But logic alone will not long compel courts to reach a conclusion which they deem undesirable. Some basis for a differentiation will be discovered which will permit another conclusion. Promise for gain, in contrast to

is hardly possible to put this right of substitution too high, and the right results more from equity, than from contract or quasi contract; unless, in so far as the known equity may be supposed to be imported into any transaction, and so to raise a contract by implication." Lord Brougham in Hodgson v. Shaw, 3 Mylne \& K. 183, at Igo (I834).

"The equity which entitles a surety to the benefit of all securities of the principal deposited with the creditor to assure payment of the debt, is wholly independent of any contract between the surety and the creditor, and indeed of any knowledge on the part of the surety of the deposit of the securities." Ames, J., in Hidden v. Bishop, 5 R. I. 29 at $3 I$ (I857).

$\approx \pi$ But it has been held that the creditor's release of such security totally discharges the surety though its value is less than the debt secured. Polak v. Everett, L. R. I Q. B. D. 699 (1876) ; Farmers' \& Merchants' Bank v. Tasche, 53 S. D. 603, 222 N. W. I39 (I928). In Eisey v. People's Bank of Bardwell, I66 Ky. 386 at 393, I79 S. W. 392 at 394 (I9I5), the court said: "It is the fact that the creditor interfered, and thereby increased the risk of the surety, and deprived him of his right of subrogation, and not the extent of injury resulting from his act, that relieves the surety." The overwhelming weight of authority discharges the surety only to the extent of the value of the security released. 2 WIIISTON, CONTRACTS \$ I232.

$\approx$ Wasco County v. New England Equitable Ins. Co., 88 Ore. 465 , 172 Pac. I26 (IgI8).

${ }^{57}$ See cases cited supra note 7 . 
promise for accommodation, became the differentiating factor. The accommodation surety's "right" to the indefinitely valuable incentive-security is a right to enjoy it in specie and his obligee's invariable performance of his correlative duty to enforce the retention clause is a condition precedent to such a surety's duty to pay; failure to enforce the clause operates as a condition subsequent. But the compensated surety's conceded "right" of subrogation to its obligee's security is a mere "right" and nothing more. The obligee's breach of his duty to withhold the percentages does not operate in its favor as a condition subsequent but merely gives rise to a cause of action in its favor for the resulting damage, as does the invasion of an ordinary right.

In summary, impairment of the equitable right of subrogation, as that right has come through the centuries to be understood, appears inadequate for the rationalization of desirable results in many of the situations where the surety claims to be discharged by the obligee's acts subsequent to the formation of the contract. No other rationalizing doctrine was available, however, when the early cases were decided which established the surety's various defenses. Implication of promise or condition to suit the requirements of justice in the particular case was to become common much later. Besides, it would not have occurred to courts, whose sympathy inclined them to discharge the surety, to consider whether a doctrine which justified such a conclusion in the case at hand might not, under other circumstances, carry them to too great lengths in his favor. No result would have seemed too favorable for a gratuitous promisor to whom the law was to deny any possibility of profit. But impairment of the right of subrogation, which was generally so adequate to the surety's protection, finally came to be viewed as practically the sole criterion for determining, in the varying situations which arose, whether the surety had a defense or not. Regretfully must the courts have held their favorite liable because they could find no impairnent of the right of subrogation where the creditor released the principal with a reservation of remedies against his surety, though it is clear that the creditor himself makes it certain by such a release that the principal will not perform as contemplated, and probably also destroys the surety's remedy of exoneration against the principal. Only when corporations promising for gain began to assert the well established suretyship defenses did the idea evolve that a breach of the "right" of subrogation need not operate as a condition subsequent but might merely give rise to a cause of action for damages. The evolution of this idea marks a great advance in the law of suretyship. If it had been applied from the beginning;- - and there is no reason why it might not have been, except the court's sympathy for the surety,-suretyship decisions would have escaped much of the criticism to which they have been subjected. 
But, notwithstanding the improvement which the use of this idea has brought about, it appears to leave a good deal yet to be desired. The "right" of subrogation is implied in the interest of justice. If it may be assumed that the purpose of a surety's undertaking is to protect his obligee from such loss in his dealings with the principal as he may not avoid by the use of reasonable prudence, the obligee should enjoy the protection of the surety's obligation as long as he exercises such prudence. The risk of loss to which an obligee subjects himself by not exercising such prudence is beyond the scope of the surety's protecting promise. The implication of a condition precedent which requires the obligee to exercise such prudence, whether in dealing with his security or directly with the principal would, it is believed, always impose upon the surety the risk which his assumption of the role of protecting promisor makes it reasonable to believe he intended to assume. The application of this theory to the release of any form of security would always require inquiry into the circumstances under which the obligee acted.

In appraising the decisions, it seems reasonable to say that most of them are open to criticism because they deny the relevancy of such circumstances. Doubtless the obligee often makes advances to enable the principal to continue performance. When this is so, no uncontemplated increase of risk results, for the incentive-security has then lost its value and neither accommodation nor compensated surety should be discharged merely because of the advance. The same conclusion should follow, if the principal is unable to perform, when the surety, whether accommodation or paid, complains of the surrender of the accumulated fund, if the payment proportionately advances performance. But if it does not have this effect, the surety, whether accommodation or compensated, should be discharged to the extent to which it fails to do so. Some of the recent decisions refuse to discharge a compensated surety to any extent if it appears that the payment went into the job and there is no indication that this conclusion is conditioned upon the principal's inability further to perform when the payment is made. ${ }^{38}$ This seems unfair to the surety because, as long as the principal can perform without it, the retained percentage has a real though indefinite security-value and the obligee's surrender of it is imprudent. The resulting uncontemplated increase of risk should totally discharge the surety, whether accommodation or compensated, if it is not to bear an uncontemplated risk or be practically denied the right to what has long been regarded as an important part of the obligee's security.

${ }^{2}$ See cases cited supra note 9. In School District v. United States Fidelity \& Guaranty Co., supra note 9, the court said, at 502, 152 Pac. at 670: "As the company was insuring for profit, it was not entitled to insist upon the withholding of the final payment, or that a particular percentage of the contract price should be retained, since it was specifically provided for in the bond which it gave." The same reasoning has been adduced to support a refusal to discharge an accommodation surety. Harlan Fuel Co. v. Wiggington, $203 \mathrm{Ky}$. 546,262 S. W. 957 ( 1924 ). 